\title{
Determinants of International R\&D Outsourcing: The Role of Trade
}

\author{
María García-Vega* and Elena Huergo \\ Dpto. de Fundamentos del Análisis Económico I. Universidad Complutense. \\ GRIPICO (Group for research in Productivity, Innovation and Competition). Universidad Complutense.
}

\begin{abstract}
This paper investigates the determinants of international $R \& D$ outsourcing, in particular the role of trade. We construct a monopolistic competition model with heterogeneous firms where outsourcing increases a firm's fixed transaction as well as its productivity. Financial constraints affect the decision to outsource R\&D more to non-exporters than to exporters. In contrast, exporters are more sensitive to a lack of information because they have higher losses when there is technology leakage. We test these predictions using a panel database of Spanish companies. The results highlight the relevance of information in competitive markets, and the role of trade to induce companies to engage in other globalization strategies.
\end{abstract}

JEL Classification: F2, L24, O3.

Keywords: R\&D outsourcing, exporters, financial constraints, technology leakage.

\footnotetext{
+ The authors are grateful for detailed comments from an anonymous referee, Christian Volpe, Luis Miguel de Castro, Lourdes Moreno, and the audiences at X Jornadas de Economía Internacional (Madrid), the ETSG 2007 Conference (Athens), the ESF/COST Workshop on "Science and Technology Research in a Knowledge-based Economy" (Leuven), the XXXII Simposio del Análisis Económico (Granada), and Workshop on "International Economics" (Zaragoza). All errors are ours. This research has been partially funded by the CICYT project SEJ2004-02525/ECON. Elena Huergo also acknowledges financial support from the CDTI (Centro para el Desarrollo Tecnológico Industrial).
}

* Corresponding author: Dpto. Fundamentos del Análisis Económico I. Facultad CC. Económicas y Empresariales. Universidad Complutense de Madrid. Campus de Somosaguas. 28223 Madrid. Spain. Emails: María García-Vega: mlgarcia@ccee.ucm.es; Elena Huergo: ehuergo@ccee.ucm.es 


\section{Introduction}

In highly competitive industries, innovation is essential for the survival of the firms. Companies have incentives to buy technological services from commercial providers, customers, universities or even competitors located around the world (Baumol, 2001). For example, in the pharmaceutical industry, a large part of the clinical tests are done by external companies in Israel, Taiwan or South Korea; Boeing subcontracts the design of some components from companies located all around the world; manufacturers of semiconductors work closely with suppliers from other countries to jointly develop new products (The Economist Intelligent Unit, 2007).

Despite the growing importance of international $R \& D$ outsourcing, little is known about its determinants. In this paper, we study the determinants to international R\&D outsourcing, in particular we analyse how trade can affect the decision to outsource R\&D internationally. We develop a theoretical model and provide empirical evidence.

Some previous studies have empirically analysed the complementarities between international R\&D outsourcing and internal R\&D (e.g., Arvanitis and Hollenstein, 2006, Braga and Willmore, 1991, and Veugelers and Cassiman, 1999). An important message from this literature is that international $R \& D$ outsourcing does not seem to substitute domestic $R \& D$, since firms need absorptive capacities to outsource $R \& D$. These papers, however, do not look at the role of trade, which is our main research question. Specifically, we analyse to what extent trade favours international R\&D outsourcing, and whether some of the determinants to outsource R\&D abroad differ between exporters and non-exporters. We focus on the factors that firms report as the most important ones for their decision to outsource R\&D: intellectual property loss, and financial constraints 
(Lewin and Couto, 2006, The Economist Intelligent Unit, 2007, R\&D magazine, 2007). We have three main sets of theoretical and empirical findings. First, we find that international R\&D outsourcing is more likely for exporters than for non-exporters. Second, we show that financial constraints affect only non-exporters. Third, we find that exporters are more sensitive than non-exporters to a lack of information that helps to monitor technological leakage.

In order to explain the link between trade and international R\&D outsourcing, we propose a model of monopolistic competition with heterogeneous firms. In the model, companies can outsource internationally, domestically, or not at all. Outsourcing increases the firms' productivity and fixed transaction costs. We assume that there is a cash-in-advance constraint at the beginning of the period, which deters the possibility to outsource unless a bank finances the transaction costs. Under borrowing constraints, the bank extends finance to a firm if the company can offer its operating profits to the creditor. The model predicts that exporters tend to outsource more abroad than nonexporters because as exporters are selling to a larger market, technological international outsourcing is relatively less costly for exporters. By trading, a firm decreases its financial constraints, which allows the purchase of technology abroad. However, a company becomes reluctant to outsource $R \& D$ internationally when there is technology leakage. We formalize this concept by assuming that a firm experiences a reduction in its demand when there are hold-up problems. This leads to exporters facing larger potential losses than non-exporters under technology leakage. The model predicts that an exporter becomes more dependent on information than a non-exporter if technology leakage can 
be partly monitored with information about the technology or about the market characteristics.

We provide empirical evidence by using data on approximately 7,000 Spanish companies for the years 2004 and 2005. We find that being an exporter increases the probability of outsourcing $R \& D$ abroad by more than one half. We show that financial constraints are obstacles to outsourcing internationally for non-exporters, but that this is not the case for exporters. By contrast, only exporters find that the lack of information on markets or on technology is an obstacle to outsourcing abroad.

This paper is related to recent contributions by Antràs and Helpman (2004) and Helpman et al. (2004). Our paper is also part of the literature of financial market frictions and firms' decisions (Cooley and Quadrini, 2001). For example, Manova (2006) shows that credit constraints determine trade patterns. In Chaney (2005) and Manova (2006) heterogeneous companies face credit constraints to finance their costs of trade. But unlike these papers, we study how financial constraints can affect the decision to outsource R\&D.

This paper is also related to the growing literature on international outsourcing (e.g., Glass, 2004, Stähler, 2007, Truett and Truett, 2008), but we analyse outsourcing of technological services instead of manufactured goods. Our contribution is that we analyse a specific channel of international knowledge transfers - the acquisition of technological services among firms.

The structure of the paper is as follows. In Section 2, we present the theoretical model. Section 3 presents the data, the empirical methodology, and the empirical results of the estimations. Section 4 concludes. 


\section{The model}

Our model builds on the Antràs and Helpman (2004) and Helpman et al. (2004) models of monopolistic competition with heterogenous firms. We analyse an industry with a measure $M$ of active firms. We assume that the economy has two sectors: one is characterized by a numeraire good, and the other by differentiated products. The preferences of a representative consumer are given by the consumption of the numeraire good plus a standard index of consumption of the differentiated products. This index reflects the consumer's taste for varieties. In this set up, the aggregate demand for any of the varieties of the differentiated product is given by $y\left(p_{j}\right)=\frac{p_{j}^{1 /(\alpha-1)}}{P} E$, where $E$ is the aggregate expenditure or the market size, $p_{j}$ is the price of the $j^{\text {th }}$ variety and $P=\int_{0}^{M} p_{z}^{\alpha /(\alpha-1)} d z$ is the weighted aggregate price index.

As in Melitz (2003), we assume that firms are heterogeneous. Companies have different levels of productivity, denoted by $\varphi>1$, associated with traditional inputs (labor, physical capital, materials...), and internal $R \& D$ resources that provide absorptive capacities. We consider that a firm's efficiency is drawn from a Pareto distribution with support $\varphi \in[1, \infty)$, and shape $\psi$. More productive firms have lower marginal costs than their less productive counterparts.

After knowing their efficiency level, firms can outsource part of their innovative activities either to companies in their country or to firms in another country. In both cases, their marginal cost decreases. The cost of producing one unit of output is equal to $1 /\left(\varphi c_{i}\right)$, 
with $c_{i} \geq 1$, for $i=0, D, F$. The constant $c_{i}$ is a multiplicative increase of productivity due to outsourcing domestically if $i=D$, or to outsourcing abroad if $i=F$, respectively. If firms do not outsource (in this case $i=0$ ), there is no productivity increase (and thus $\left.c_{0}=1\right)$. This multiplicative form ensures that more productive firms benefit relatively more from outsourcing than less productive companies. Our justification for this specification is that firms with higher productivity have higher absorptive capacity than less productive firms. The firm's productivity increases if the firm outsources, which in the model implies that $C_{F}=\zeta \cdot c_{D}>c_{0}=1$, with $\zeta>0$. If $\zeta>1$, outsourcing abroad is more productive than domestic outsourcing. For some industries it is a question of the complexity of technology. For example, aerospace companies buy some pieces from very specialized foreign providers. In this line, Brusoni et al. (2001), Cesaroni (2004), and Hagedoorn (1993) show that technology sources in some fields provided by suppliers from other countries are the best option for the firm to keep up to date. The reason is that international outsourcing can offer the possibility to buy the best available technology.

We model the cost of outsourcing as a transaction fixed cost denoted by $f_{i}$, for $i=D, F$ (e.g., Feenstra et al., 2004). If the firm does not outsource, it bears a fixed cost $f_{0}$. R\&D outsourcing requires close collaboration between the research teams. Therefore, international outsourcing implies higher communication, coordination, and organizational costs than domestic outsourcing. In the model, this assumption implies that $f_{F}>f_{D}>f_{0} \geq 0$ (Antràs and Helpman, 2004).

The financial structure of the model follows Cooley and Quadrini (2001). Each firm faces a cash-in-advance constraint: at the beginning of every period, it requires a bank to finance the outsourcing investment and the fixed cost. Both the bank and the borrower are 
risk-neutral and only one-period debt contracts are signed with the bank. We consider that a constant exogenous shock can force companies to exit the market (Melitz, 2003). If the firm defaults, the bank liquidates the company, and the firm immediately exits the industry. The bank makes a take-it-or-leave-it offer to the firm, and issues funds at an interest rate $r$. The bank chooses the interest rate such that the expected repayment from the loan is equal to the repayment of a riskless loan, as follows:

$$
\left(1+r_{0}\right) f_{i}=(1+r) f_{i} \lambda+(1-\lambda) C, \quad \text { with }\left(1+r_{0}\right) f_{i}>C, \text { for } i=0, D, F .
$$

The left-hand side of equation (1) gives the return of the loan at the riskless interest rate $r_{0}$. The right-hand side of the equation says that with probability $\lambda$, the firm can repay its debts, and with probability $1-\lambda$, it goes bankrupt. In the case of bankruptcy, the bank gets the collateral denoted by $C{ }^{1}$

A firm's objective consists of maximizing profits subject to the constraints. This leads to the standard pricing rule $p\left(\varphi, c_{i}\right)=1 /\left(\alpha \varphi c_{i}\right)$. We call $\Pi\left(\varphi, c_{i}\right)$ the maximum profit of a firm of type $\varphi$ that chooses outsourcing of type $i$ after applying this pricing rule. We consider that $\zeta>1$; this rules out the case where firms always prefer not to outsource R\&D abroad. This assumption seems reasonable for the data that we use in our empirical analysis. On average, companies with international outsourcing are eight percentage points more likely to have process innovations, three percentage points more likely to obtain product innovations, and they are more productive (measured as the logarithm of sales over number of employees) than firms with domestic outsourcing. The model includes a zero-profit condition and a condition that says that the mass of new entrants in every period exactly

\footnotetext{
${ }^{1}$ We follow closely Melitz (2003) by assuming that there is an exogenous probability of bankruptcy independent of firm's productivity. We want to keep the model as simple and as tractable as possible and at the same time being able to study the impact of trade on the endogenous productivity thresholds.
} 
replaces the mass of incumbents that exit (Meltiz, 2003). Under the previous assumptions, there exist two unique efficiency thresholds. ${ }^{2}$ The first threshold refers to the efficiency such that companies are indifferent with respect to either outsourcing domestically or not outsourcing, and the second one to outsourcing either domestically or abroad. They are denoted by $\varphi_{D}$ and $\varphi_{F}$, respectively, and they are calculated as the efficiency levels for which maximum profits of the decisions are equalized. We obtain a partition of firms. If a firm's efficiency is $\varphi>\varphi_{F}$, the company prefers to outsource internationally; if $\varphi \in\left(\varphi_{D}, \varphi_{F}\right)$, the firm outsources in the domestic market; and finally, if $\varphi<\varphi_{D}$, the company chooses not to outsource. ${ }^{3}$

\subsection{Open economy model}

We now assume that there are two identical countries that trade the varieties of $Y$. Trade for continuous exporters involves a variable per unit cost of the good that is transported. ${ }^{4}$ This variable cost implies that for one unit of a good to arrive at the final destination, $\tau>1$ units of the good need to be shipped. While a firm's prices in the domestic market are the same as before, $p\left(\varphi, c_{i}\right)=1 /\left(\alpha c_{i} \varphi\right)$, exporters set prices in the foreign market as in the following expression $p_{x}\left(\varphi, c_{i}\right)=\tau /\left(\alpha c_{i} \varphi\right)$.

\footnotetext{
${ }^{2}$ Details of the proofs, and the database can be found in the working paper version of this article (GarcíaVega and Huergo, 2008). We provide an abbreviated discussion here in the interest of space.

${ }^{3}$ Firms with efficiency equal to the thresholds are indifferent between the different types of outsourcing. This is consistent with the case in which firms pursue both domestic and international outsourcing. The model could be extended by adding a fixed cost for double-sourcing. If this cost is higher for doublesourcing than for international outsourcing only, the model would predict that only the most productive firms can outsource both domestically and internationally.

${ }^{4} \mathrm{We}$ also assume that there is a sunk cost to start exporting. In the empirical analysis, we study the decision to outsource for continuous exporters. For this reason, we assume that exporters have already paid the sunk cost of entry into the foreign market. The sunk trade cost implies that only some firms can export, and that there exists a unique efficiency threshold such that firms with efficiency lower than the threshold do not export, while firms with efficiency higher than the threshold decide to export (Melitz, 2003).
} 
We analyze whether the probability of outsourcing is higher for exporters than for non-exporters. In our framework, this is equivalent to determining whether the efficiency threshold to outsource is lower for exporters than for non-exporters. The difference between the minimum thresholds to outsource depends on the differences between the profits of exporters and non-exporters. Exporters have on average higher revenues than non-exporters before outsourcing, consequently fixed transaction costs associated with outsourcing become relatively lower in terms of the total revenue. This result leads to the following proposition.

Proposition 1: If $\zeta>1$, the probability of outsourcing $R \& D$ abroad is higher for exporters than for non-exporters.

\subsection{Open economy model with financial constraints}

There is much evidence showing that financial constraints have important implications for firm decisions (e.g., Clementi and Hopenhayn, 2006). These constraints can influence a firm's purchase of technology. In this section, we introduce financial constraints in the model, distinguishing their effect for exporters and non-exporters.

We assume that banks only extend finance to the firm if the company can offer its operating profits $\Pi_{k}^{0}\left(\varphi, c_{i}\right)$ to the creditor, i.e. $(1+r) f_{i} \leq \Pi_{k}^{0}\left(\varphi, c_{i}\right)$, with $k=n x$ for nonexporters, and $k=x$ for exporters (e.g. Manova, 2006), for $i=D, F$. A company obtains financial credit if its efficiency level is as large as the threshold $\bar{\varphi}_{i, k}$. This threshold is calculated by solving for the efficiency level such that operating profits are equal to the repayment of the loan plus the interest, for both exporters and non-exporters, respectively. In our analysis, we only focus on financial constraints for R\&D investments 
because they are riskier than other type of investments and therefore they can imply high financial constraints. ${ }^{5}$

Trade increases operating profits. Therefore, the impact of financial constraints on the decision to outsource is more important for non-exporters than for exporters. The analytical reason is that the increase in the efficiency threshold needed to outsource when there are financial constraints (compared with the situation without financial frictions) is larger for non-exporters than for exporters: $\left(\bar{\varphi}_{i, n x}-\varphi_{i, n x}\right)-\left(\bar{\varphi}_{i, x}-\varphi_{i, x}\right)>0$, and this differential increases as financial constraints increase. This result can be expressed as:

Proposition 2: The negative effect of financial constraints on the probability of outsourcing $R \& D$ abroad is higher for non-exporters than for exporters.

\subsection{Open economy model with technology leakage}

A key characteristic of R\&D outsourcing, and, particularly, outsourcing abroad, is that it induces some risks in a situation of imperfect contracts, hold-up problems, and cultural differences (e.g. Baccara, 2007, Lai et al., 2009, Ornelas and Turner, 2008). Companies can be reluctant to outsource because they can be exposed to subcontractors, especially in countries with poor intellectual property rights. The next step of our analysis is to look at the impact of technology leakage in an open economy framework. In order to simplify the model, we assume that there are no financial constraints in the economy.

\footnotetext{
${ }^{5}$ Incorporating a detailed analysis of financial constraints for market entry can provide additional insights about the effects of financial liberalization policies. More liquidity can increase the number of companies that enter into the market lowering minimum efficiency thresholds. Additionally, it can become easier to obtain financial resources to cover the fixed costs of outsourcing.
} 
As in Lai et al. (2009), we consider that firms experience a reduction in their demand when there is technology leakage. That is, $y\left(p_{j}, \delta\right)=\left(\delta p_{j}{ }^{1 /(\alpha-1)} E\right) / P$ with $\delta \in(0,1)$ if there is leakage, and $\delta=1$ if there is no leakage. The variable $\delta$ reflects the importance of technology leakage. We assume that it depends on the capacity to monitor a subcontractor. We consider that companies can monitor better if they have some knowledge of the technological characteristics of the innovation or the market. These assumptions guarantee that, from the point of view of the company, information reduces the potential hold-up problem. In this framework, the pricing rule does not change with respect to the base case. Under the previous simplified assumptions, the negative effect of leakage on profits is more severe for exporters than for non-exporters since $\frac{\partial \Pi_{x}\left(\varphi, c_{i}, \delta\right)}{\partial \delta}-\frac{\partial \Pi_{n x}\left(\varphi, c_{i}, \delta\right)}{\partial \delta}>0$. We summarize this result in the following proposition.

Proposition 3: When companies decide to outsource internationally, the lack of information is an obstacle that is relatively more important for exporters than for nonexporters.

In summary, our model predicts that: (i) When a firm exports, it becomes more likely to outsource (Proposition 1). (ii) Trade has two indirect effects on the decision to outsource technology abroad. Firstly, trade makes exporters less financially constrained than non-exporters. This effect facilitates international $R \& D$ outsourcing for exporters. The theory predicts that financial constraints decrease the probability of outsourcing internationally mostly for non-exporters (Proposition 2). Secondly, the model shows that exporters have larger losses than non-exporters in case of technology leakage. When 
there is a lack of information that helps to monitor subcontractors, exporters are more exposed to the potential danger of international outsourcing than non-exporters. As a result, the model predicts a negative relationship between a lack of information and international $\mathrm{R} \& \mathrm{D}$ outsourcing for exporters, and a weaker relationship for non-exporters (Proposition 3). In the next section, we investigate these predictions empirically.

\section{The empirical evidence}

\subsection{The data and the main variables}

The data set that we use comes from a survey of innovating Spanish firms (Panel de Innovación Tecnológica, PITEC). ${ }^{6}$ In order to avoid simultaneity problems, some variables related to exporting activity are included with a one-period lag. The empirical analysis is conducted for the year 2005, for which we have information from 7,205 firms. We consider that a firm is outsourcing $R \& D$ if the $R \& D$ provider is outside of the company. In the survey, there are 2,759 firms that outsource $R \& D, 447$ of which are located abroad.

The main interest of our analysis consists of testing the predictions developed in the previous section: to what extent exports increase international R\&D outsourcing (proposition 1), and whether exporters and non-exporters are influenced differently by financial constraints (proposition 2), and by information problems (proposition 3) at the moment of international R\&D outsourcing. Our data provides detailed information on these variables at the firm level. Each firm indicates its purchases of $R \& D$ services from

\footnotetext{
${ }^{6}$ The Spanish National Institute of Statistics constructs this database on the basis of the annual Spanish responses to the Community Innovation Survey (CIS). The survey is targeted to manufacturing and services companies whose main economic activity corresponds to sections $\mathrm{C}, \mathrm{D}$, and $\mathrm{E}$ of NACE 93, except nonindustrial companies because of the imprecision of methodological marking in the international context by other branches of activity.
} 
other companies or institutions at foreign locations. This variable is our measure of $R \& D$ outsourcing. Companies report their exports. We define a dummy variable for being an exporter, and a variable for export intensity, constructed as the ratio of exports over total employment.

Companies answer questions about the factors that prevent them to innovate. We construct a variable that measures a firm's financial constraints. The companies are asked how important the lack of funds, the lack of finance, and innovation costs are as factors that hamper their innovation. For each of the factors, a company can answer that the importance of the factor was high, intermediate, or low, or that the factor was not relevant. We assign a number that varies from zero (not relevant) to three (high importance) for each answer. Then, we calculate the average importance of the cost factors. This is our variable lack of finance.

We construct a variable that quantifies the value of the information for the company. In the survey, the companies are asked how important the lack of information on technology, and the lack of information on markets are as factors that hamper their innovation. Again, for each of the factors, companies can answer that the importance of the factor was high, intermediate or low, or that the factor was not relevant. We calculate the variable lack of information in the same way as the variable lack of finance. This variable is our measure of the capacity of a firm to monitor its subcontractors. We consider that information is a relevant asset for the firm because it helps to avoid technology leakage.

\subsection{Descriptive analysis}


During 2005, around half of the continuous innovating firms were actively engaged in external R\&D expenditures. ${ }^{7}$ However, only a small percentage of those companies (9.4\%) bought R\&D abroad.

Proposition 1 states that the probability of outsourcing R\&D abroad is higher for exporters than for non-exporters. This is a relationship that is strongly supported by the data. Our first empirical observation is depicted in Figure 1. There, we show that there are almost twice as many exporters as non-exporters that outsource abroad.

\section{INSERT FIGURE 1}

In Table 1, we show some descriptive statistics of the variables of our empirical specification. The exporting intensity is higher for companies with international R\&D outsourcing than for companies with national outsourcing or for firms with only internal R\&D expenditures. Again, this pattern illustrates that international outsourcing and export activity are strongly positively related.

\section{INSERT TABLE 1}

Figure 2 displays our second empirical observation. We compare the importance of the lack of finance for the firm by exporting status. Among the companies that do not outsource internationally, non-exporters are more concerned about their lack of financial resources than exporters. However, this obstacle is less relevant for non-exporters than for exporters once firms outsource abroad. This pattern is consistent with our Proposition 2. This feature suggests that non-exporters have to face fewer financial constraints than exporters in order to outsource abroad.

\footnotetext{
${ }^{7}$ We call a firm with positive innovation expenditures both in 2004 and 2005 a "continuous innovator"
} 
We depict our third empirical observation in Figure 3. We compare the importance of the lack of information for the firm by its exporting status. For companies that do not outsource internationally, we can see that exporters are more influenced by the lack of information than non-exporters. Once companies outsource internationally, exporters are less concerned about the lack of information than non-exporters. We interpret this variation as reflecting that exporters need to accumulate more information than non-exporters in order to outsource, which is consistent with Proposition 3.

\section{INSERT FIGURES 2 AND 3}

In summary, the descriptive analysis supports the propositions. In the next section, we test our predictions econometrically by controlling for potential covariates.

\subsection{The empirical specification}

We now turn to examining the determinants of international R\&D outsourcing at the firm level. We simultaneously estimate two equations by maximum likelihood. The first one describes a firm's decision to contract technological activities abroad (selection equation). The second equation refers to the intensity of the $R \& D$ expenditure abroad. The selection equation is given by:

$$
r d=\left\{\begin{array}{lll}
1 & \text { if } & \varphi-\varphi_{F}=w^{\prime} \alpha+\varepsilon>0 \\
0 & \text { if } & \varphi-\varphi_{F}=w^{\prime} \alpha+\varepsilon \leq 0 .
\end{array}\right.
$$

The intensity equation, conditional on the firm reporting international R\&D outsourcing, is expressed as in the following specification:

$$
r=\left\{\begin{array}{lll}
r^{*}=z^{\prime} \beta+e & \text { if } & r d=1 \\
0 & \text { if } & r d=0 .
\end{array}\right.
$$


In equation (2), $r d$ is the observed binary endogenous variable equal to one if a given firm reports international $R \& D$ outsourcing, and zero for non-R\&D reporters. The vector $w$ reflects factors that influence this decision. In equation (3), the variable $r$ stands for international R\&D outsourcing expenditures, and the vector $z$ represents its determinants. We denote the error terms as $e$ and $\varepsilon$, and we assume that they are distributed as a normal bivariate with zero mean, variances $\sigma_{\varepsilon}^{2}=1$ and $\sigma_{e}^{2}$, and correlation coefficient $\rho_{e \varepsilon}$.

Vectors $w$ and $z$ include, among others, the variables lack of finance and lack of information, and the indicators of the exporting activity. Notice that R\&D outsourcing abroad can stimulate exports, given that outsourcing can allow access to a wider technological network and the accommodation of the firm's products to the specificities of foreign markets. This can generate a potential endogeneity problem. In order to avoid this problem, we include the indicators of the exporting activity lagged one period. We also incorporate each of the lack of finance and lack of information variables multiplied by the being an exporter dummy variable (interacted variables) in the regression. We denote these variables as lack of finance: exporters, lack of finance: non-exporters, lack of information: exporters, and lack of information: non-exporters, respectively.

In the theoretical model, each firm has an ex ante efficiency $\varphi$ associated with the productivity of traditional inputs and R\&D resources. Recall that we assume that firms with ex ante higher efficiency have also higher absorptive capacity. Therefore, we include in the regressions a group of variables that reflect internal capabilities such as economies of scale coming from specialization, and firms' specific advantages. We include the variables: $R \& D$ employment, a binary variable for companies with continuous 
$R \& D$ engagement, and firm size. Under the existence of economies of scale, we expect that firm size affects outsourcing positively. Additionally, we include two dummy variables that reflect that companies produce with intensive technological techniques: a variable denoting whether the firm is part of a multinational, and whether it has applied for patents. ${ }^{8}$ We also include two dummies reflecting whether the firm belongs to a hightech manufacturing industry, or to the high-tech services sector (to classify sectors, we follow the Eurostat/OECD classification, 2007). Finally, we include a set of geographical dummies.

In addition, if a firm's ex ante efficiency is higher than a certain threshold $\varphi_{F}$, the firm finds outsourcing abroad profitable. In the model, this threshold depends on the lack of finance, the lack of information, export activity, and relative gains in productivity between the different types of outsourcing (the parameter $\zeta$ ), among other factors. Following these considerations, we also include in our specification variables that could make foreign outsourcing more productive than domestic outsourcing. We consider that market focused companies can obtain more productivity gains if they outsource abroad than less market focused firms. Companies report the importance of institutional sources of information, internal sources of information, and market sources of information in order to innovate. These variables can measure how market-focused the companies are. We consider that companies that obtain information from universities, other public research centres or internal sources are less market-focused than companies that prefer market sources of information. Therefore, we expect that these two groups of firms

\footnotetext{
${ }^{8}$ For example, Chang and Robin (2006) show that firm size is a key variable for explaining technology imports in Taiwanese firms. An important result in the literature refers to the fact that multinationals produce with intensive technological techniques (e.g., Girma and Görg, 2004).
} 
obtain fewer gains from outsourcing than companies that obtain many innovations from the market.

We have estimated both equations with the same set of explanatory variables $(z=w)$, with two exceptions: The export activity is included in the selection equation through the dummy variable being an exporter, while in the intensity equation it is introduced in terms of export intensity. The other exception is the continuous $R \& D$ engagement that we expect to be relevant for the outsourcing decision, but we assume that it has no effect on outsourcing intensity. The model predicts that the decision to outsource abroad instead of domestically depends on both costs differentials and the decision to maintain regular internal $\mathrm{R} \& \mathrm{D}$ activities (through being more productive). However, we consider that the intensity of outsourcing abroad mostly depends on costs differentials. The reason is that continuous $R \& D$ tends to affect the decision to engage in other international activities (Griffith et al., 2006). However, the intensive margins are more related to intensity variables than the extensive margins. For example, Chaney (2008) and Ruhl (2005) argue that when there are transitory shocks most of the firm's adjustments happen at the intensive margin, whereas in response to permanent shocks the extensive margins adjust.

\subsection{The results}

We turn to the analysis of international R\&D outsourcing. We estimate equations (2) and (3) using a Generalized Tobit model without including the interacted variables. ${ }^{9}$ The first column of Table 3 exhibits the coefficients of the probit model for the decision to

\footnotetext{
9 The interacted variables are the variables lack of finance and lack of information multiplied by the dummy variable being an exporter.
} 
outsource $\mathrm{R} \& \mathrm{D}$ internationally. The second one corresponds to the intensity, taking the selection term into account. The correlation term $\rho_{e \varepsilon}$ is statistically different from zero, pointing out the need to estimate a selection model for the observed intensity.

\section{INSERT TABLE 2}

Being an exporter increases the probability of outsourcing R\&D abroad by 5 percentage points. The estimated coefficients in column (2) show that export intensity yields a significant effect in the outsourcing expenditures. To place this result in perspective, the probability to outsource abroad of an average company with external $R \& D$ expenditures is $9.4 \%$, which implies that exporting increases the probability to outsource internationally by more than one half. This result is consistent with our Proposition 1, and our first empirical observation, supporting the hypothesis of complementarities between both types of internationalisation strategies.

Our theory predicts that financial constraints and information are major determinants for international $\mathrm{R} \& \mathrm{D}$ outsourcing. The estimations show that lack of information reduces the probability of outsourcing by approximately 2 percentage points, but it has a negligible influence on the quantity outsourced abroad. By contrast, we find that the lack of finance has a negative impact on the quantity that is outsourced abroad, while having no influence on the outsourcing decision.

Conditional on reporting external R\&D expenditures, most variables have the expected positive impact on the propensity to contract $R \& D$ abroad. Larger firms are more likely to outsource than smaller companies, although the relationship is non-linear. Firms that consider market sources of information as crucial are keener to outsource internationally. However, companies that find institutional sources of information 
important give priority to domestic locations. This is what we would expect if they were less market-focused.

The previous estimations have the limitation that we cannot distinguish whether the impacts of financial constraints and information problems differ between exporters and non-exporters. We address this issue by including the interacted variables in the specification. The results of the estimations are reported in Table 3. We find strong confirmation for our Proposition 3. In columns (1) and (2), we show that for exporters a lack of information on technology or on markets decreases the probability of outsourcing R\&D abroad by approximately 3 percentage points, while for non-exporters the impact of this variable is negligible.

We also find some support for Proposition 2. The lack of finance variable has a negative effect on the outsourcing expenditure only for non-exporters but it has no effect on the decision to outsource, either for exporters or for non-exporters. Plausibly, smaller firms tend to be more financially constrained than large companies. ${ }^{10}$ Therefore, firm size can be negatively correlated with lack of finance. This simultaneity can induce a bias in the estimated coefficient for non-exporters. To avoid this simultaneity problem, columns (3) and (4) present the regressions excluding the variable size in the estimations. The results are statistically significant: lack of finance affects the decision to outsource R\&D abroad but only for non-exporters, as Proposition 2 states. Financial constraints lead to a decrease in international $\mathrm{R} \& \mathrm{D}$ outsourcing by non-exporters of almost 2 percentage points, and it has no effect on exporters. This finding suggests that exporters outsource abroad more than non-exporters due to lower financial constraints, in line with our Proposition 2, and not

\footnotetext{
${ }^{10}$ For example Carpenter and Petersen (2002) show that the growth of most small firms is constrained by internal finance.
} 
only because they have advantages in finding suppliers abroad. These results are consistent with our theoretical model and with the empirical observations. ${ }^{11}$

\section{INSERT TABLE 3}

\section{Conclusions}

In this paper, we study the determinants of international R\&D outsourcing by analysing the role of trade, financial constraints, and information. We develop a model of monopolistic competition with heterogeneous firms. The model shows that the probability of outsourcing $\mathrm{R} \& \mathrm{D}$ abroad is higher for exporters than for non-exporters. Furthermore, financial constraints decrease the probability of outsourcing internationally. This effect is more important for non-exporters than for exporters. By contrast, exporters have major losses if there is technology leakage. It makes them more sensitive to obtaining information that helps to monitor their outsourced R\&D.

The empirical results are consistent with the predictions of the model. The probability to outsource abroad of an average company with external R\&D expenditures is $9.4 \%$. Being an exporter increases this probability by around 5.5 percentage points. Financial constraints reduce the probability of outsourcing abroad for non-exporters, by 2 percentage points. For exporters, we find no relationship between outsourcing abroad and financial constraints. The lack of information on technology or on markets reduces the probability of outsourcing abroad only for exporters, by around 3 percentage points.

International $\mathrm{R} \& \mathrm{D}$ outsourcing is becoming a rapidly growing source of technological flows that can decrease productivity differences across countries. The type

\footnotetext{
${ }^{11}$ As a robustness test, we examine the determinants of R\&D outsourcing only for exporters. The estimated coefficients are in line of those calculated in Table 3. For simplicity, these estimations are not reported. They are available in the working paper version of the article.
} 
of public policies to promote international acquisitions of $R \& D$, and therefore to enhance the country's technological advantage, can differ depending on the internationalization of the firm. Stronger intellectual property rights can induce exporters to outsource R\&D internationally because it can reduce the hold-up problem. However, innovative nonexporters can require soft loans, grants, or investments from specialized financial organizations, which in turns should make them less financially constraint. An aspect that remains to be studied is the consequences of international $R \& D$ outsourcing for the domestic industry. Relative to public policy, we consider this to be an important issue to be analysed in future research.

\section{References}

Antràs, P, and E. Helpman (2004), "Global Sourcing", Journal of Political Economy 112(3) pp. 552-580.

Arvanitis, S. and H. Hollenstein (2006), "Determinants of Swiss firms' R\&D activities at foreign locations. An empirical analysis based on firm-level data", Swiss Federal Institute of Technology Zurich Working Paper No. 127.

Baccara, M. (2007), “Outsourcing, Information Leakage and Consulting Firms", RAND Journal of Economics 38(1), pp. 269-289.

Baumol, W. (2001), "When is inter-firm coordination beneficial? The case of innovation", International Journal of Industrial Organization 19(5), pp. 727-737.

Braga, H. and L. Willmore (1991), "Technological imports and technological effort: An analysis of their determinants in Brazilian firms", Journal of Industrial Economics 39(4), pp. 421-432.

Brusoni, S., Prencipe, A., and K. Pavitt (2001), "Knowledge specialization, organizational coupling, and the boundaries of the firm: why do firms know more than they make?", Administrative Science Quarterly 46(4), pp. 597-621.

Carpenter, R. and B. Petersen (2002), "Is the Growth of Small Firms Constrained by Internal Finance?", The Review of Economics and Statistics 84(2), pp. 298-309. 
Cesaroni, F. (2004), "Technological outsourcing and product diversification: do markets for technology affect firms' strategies?”, Research Policy 33(10), pp. 1547-1564.

Chaney, T. (2005), "Liquidity constrained exporters", available at http://home.uchicago.edu/ tchaney/research/ConstrainedExporters.pdf.

Chaney, T. (2008), "Distorted gravity: The intensive and extensive margins of international trade", American Economic Review, 98(4), pp.1707-1721.

Chang, C. and S. Robin (2006), "Doing R\&D and/or importing technologies: The critical importance of firm size in Taiwan's manufacturing industries", Review of Industrial Organization 29(3), pp. 253-278.

Clementi, G. and H. Hopenhayn (2006), "A theory of financing constraints and firm dynamics", Quarterly Journal of Economics 121(1), pp. 229-265.

Cooley, T. and V. Quadrini (2001), "Financial markets and firm dynamics", American Economic Review 95(5), pp. 1286-1310.

Eurostat (2007), High-tech industry and knowledge-intensive services, available at http://europa.eu.int/estatref/info/sdds/en/htec/htec_agg_nace.pdf.

Feenstra, R. and G. Hanson (1999), "The impact of outsourcing and high-technology capital on wages: estimates for the United States 1979 - 1990", Quarterly Journal of Economics 114(3), pp. 907-40.

García-Vega, M. and E. Huergo (2008), "Determinants of International R\&D Outsourcing: The Role of Trade", D.T. No 9790, Biblioteca Complutense, UCM.

Glass, A. (2004), "Outsourcing under imperfect protection of intellectual property", Review of International Economics, 12(5) pp. 867-884.

Girma, S. and H. Görg (2004), "Outsourcing, foreign ownership and productivity: Evidence from UK establishment level data", Review of International Economics 12(5), pp. 817-832.

Griffith, R., Huergo, E., Mairesse, J. and B. Peters (2006), "Innovation and productivity across four European countries", Oxford Review of Economic Policy 22(4) pp. 483-498.

Hagedoorn, J. (2002), "Inter-firm R\&D partnerships: an overview of major trends and patterns since 1960", Research Policy 31(4) pp. 477-492. 
Helpman, E., Melitz, M. and S. Yeaple (2004), "Export versus FDI with heterogeneous firms", American Economic Review 94(1), pp. 300-316.

Lai, E., Riezman, R. and P. Wang (2009), “Outsourcing of innovation”, Economic Theory 38(3), pp. 485-515.

Lewin, A. and V. Couto (2006). Next Generation Offshoring. The Globalization of Innovation. Duke C.I.B.E.R.

Manova, K. (2006), "Credit constraints, heterogeneous firms, and international trade", NBER Working Paper No. 14531.

Melitz, M. (2003), "The impact of intra-industry reallocations and aggregate industry productivity", Econometrica 71(6), pp. 1695-1726.

Ornelas, E. and J. Turner (2008), "Trade liberalization, outsourcing, and the hold-up problem", Journal of International Economics 74(1) pp. 225-241.

Ruhl, K. (2008), "The International Elasticity Puzzle", available at http://www.kimjruhl.com/research/.

$R \& D$ magazine, June 2007.

Stähler, F. (2007), "A model of outsourcing and foreign direct investment", Review of Development Economics, 11(2) pp. 321-332.

The Economist Intelligent Unit (2007), "Sharing the Idea. The emergence of global innovation networks", The Economist.

Truett L. and D. Truett (2008), "Insourcing, outsourcing, and unemployment in the Spanish Auto industry", Review of Development Economics, 12(4) pp. 702-713.

Veugelers, R. and B. Cassiman (1999), "Make and buy in innovation strategies: evidence from Belgian manufacturing firms", Research Policy 28(1) pp. 63-80. 
Figure 1

R\&D outsourcing by exporting activity in 2005 .

(Percentage of firms in the sample of firms with external R\&D expenditures)

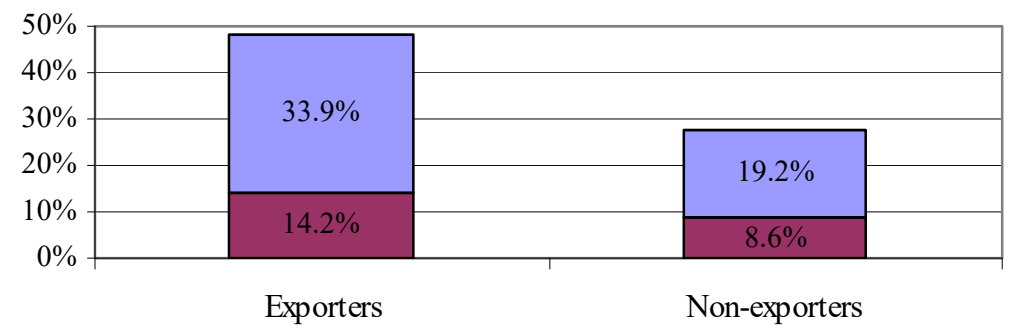

Firms without international R\&D outsourcing

Firms with international R\&D outsourcing

\section{Figure 2}

Lack of finance by exporting activity in 2005

(Mean value in the sample of firms with external R\&D expenditures)

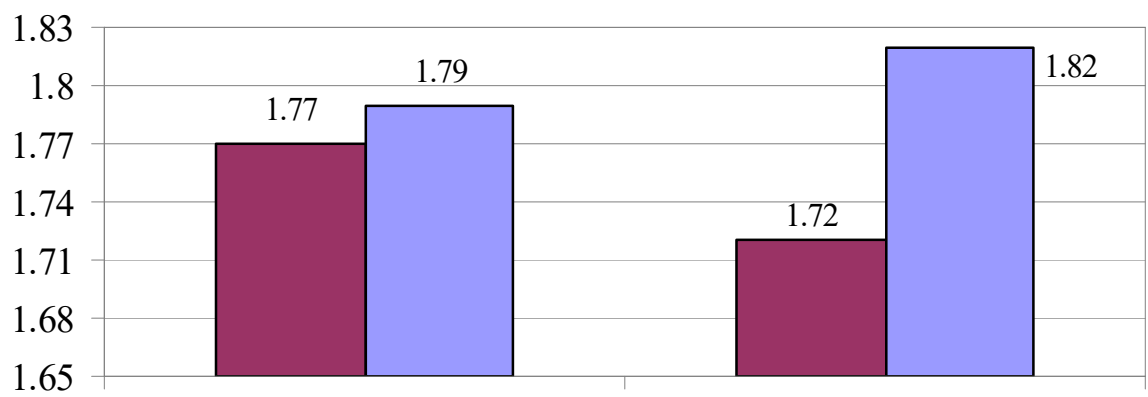

Exporters

Non-exporters

$\square$ Firms with international outsourcing

$\square$ Firms without international outsourcing 
Figure 3

Lack of information by exporting activity in 2005

(Mean value in the sample of firms with external R\&D expenditures)

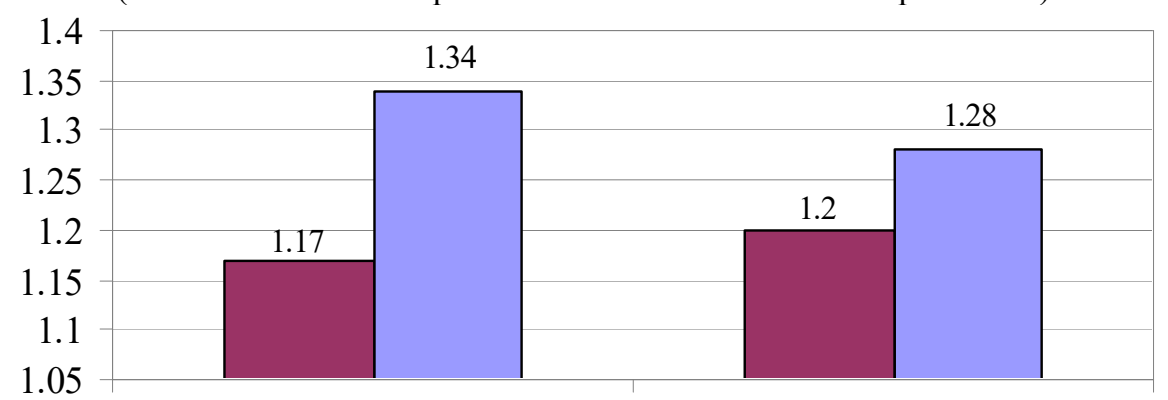

Exporters Non-exporters

Firms with international outsourcing

$\square$ Firms without international outsourcing

Table 1

Descriptive Statistics

\begin{tabular}{|l|c|c|c|c|c|c|}
\hline & \multicolumn{2}{|c|}{$\begin{array}{c}\text { Firms with R\&D } \\
\text { expenditure }\end{array}$} & \multicolumn{2}{c|}{$\begin{array}{c}\text { Firms with external } \\
\text { R\&D expenditure }\end{array}$} & \multicolumn{2}{c|}{$\begin{array}{c}\text { Firms with } \\
\text { international } \\
\text { outsourcing }\end{array}$} \\
\hline & Mean & Std. Dev. & Mean & Std. Dev. & Mean & Std. Dev. \\
\hline R\&D expenditure at foreign locations (in log.) & 0.53 & 2.35 & 1.28 & 3.52 & 10.56 & 2.08 \\
\hline Exporter & 0.57 & 0.49 & 0.63 & 0.48 & 0.74 & 0.44 \\
\hline Exporter (t-1) & 0.37 & 0.48 & 0.45 & 0.50 & 0.59 & 0.49 \\
\hline Export intensity (in log.) & 5.70 & 5.11 & 6.32 & 5.09 & 7.64 & 4.85 \\
\hline Lack of finance & 1.80 & 0.89 & 1.80 & 0.88 & 1.75 & 0.88 \\
\hline Lack of information & 1.27 & 0.78 & 1.30 & 0.77 & 1.18 & 0.73 \\
\hline Proxies for market proximity & & & & & & \\
\hline Internal sources of information & 0.62 & 0.48 & 0.64 & 0.48 & 0.69 & 0.46 \\
\hline Institutional sources of information & 0.18 & 0.38 & 0.26 & 0.44 & 0.26 & 0.44 \\
\hline Market sources of information & 0.53 & 0.50 & 0.58 & 0.49 & 0.69 & 0.46 \\
\hline Absorptive capacity & & & & & & \\
\hline Continuous R\&D engagement & 0.69 & 0.46 & 0.70 & 0.46 & 0.84 & 0.37 \\
\hline R\&D employment (\% over total employment) & 23.14 & 28.41 & 24.64 & 30.14 & 27.10 & 30.57 \\
\hline Multinational: subsidiary & 0.13 & 0.34 & 0.16 & 0.37 & 0.22 & 0.41 \\
\hline Multinational: parent company & 0.07 & 0.25 & 0.09 & 0.29 & 0.11 & 0.31 \\
\hline Patent & 0.17 & 0.38 & 0.22 & 0.41 & 0.33 & 0.47 \\
\hline Technological cooperation & 0.39 & 0.49 & 0.55 & 0.50 & 0.59 & 0.49 \\
\hline Size (number of employees) & 241.8 & 1554.8 & 336.7 & 2050.8 & 353.1 & 930.8 \\
\hline Geographical regions & & & & & & \\
\hline Basque country & 0.13 & 0.34 & 0.14 & 0.35 & 0.12 & 0.33 \\
\hline Catalonia & 0.26 & 0.44 & 0.22 & 0.42 & 0.32 & 0.46 \\
\hline Madrid & 0.14 & 0.35 & 0.13 & 0.33 & 0.17 & 0.38 \\
\hline & & & & & & \\
\hline
\end{tabular}


Table 2

Determinants of international R\&D outsourcing

Generalized Tobit model

\begin{tabular}{|c|c|c|c|c|c|c|}
\hline & \multicolumn{6}{|c|}{ All firms } \\
\hline & \multicolumn{3}{|c|}{$\begin{array}{c}\text { (1) } \\
\text { Locating R\&D abroad }\end{array}$} & \multicolumn{3}{|c|}{$\begin{array}{c}(2) \\
\text { Foreign R\&D expenditure }\end{array}$} \\
\hline & \multicolumn{2}{|c|}{ Coefficient } & \multirow{3}{*}{$\begin{aligned} \text { Std. E. } \\
0.068\end{aligned}$} & \multicolumn{2}{|c|}{ Coefficient } & Std. E. \\
\hline Exporter $(\mathrm{t}-1)$ & 0.302 & $* * *$ & & & & \\
\hline Export intensity (t-1) & & & & 0.060 & ** & 0.026 \\
\hline Lack of finance & -0.002 & & 0.040 & -0.259 & ** & 0.127 \\
\hline Lack of information & -0.127 & $* * *$ & 0.044 & -0.266 & & 0.167 \\
\hline Proxies for market proximity & & & & & & \\
\hline Internal sources of information & 0.031 & & 0.068 & -0.252 & & 0.218 \\
\hline Institutional sources of information & -0.163 & ** & 0.072 & 0.096 & & 0.287 \\
\hline Market sources of information & 0.241 & $* * *$ & 0.067 & 0.632 & ** & 0.248 \\
\hline Absorptive capacity & & & & & & \\
\hline Continuous R\&D engagement & 0.146 & & 0.089 & & & \\
\hline R\&D employment & 0.350 & $* * *$ & 0.111 & 0.928 & & 0.894 \\
\hline Multinational: subsidiary & 0.212 & $* * *$ & 0.080 & 0.725 & $* *$ & 0.289 \\
\hline Patent & 0.235 & $* * *$ & 0.070 & 0.640 & $* *$ & 0.290 \\
\hline Size & 0.0003 & $* * *$ & $0.9 \mathrm{E}-04$ & 0.001 & $* * *$ & 0.0004 \\
\hline Size squared & $-3.0 \mathrm{E}-08$ & $* *$ & $1.2 \mathrm{E}-08$ & $-1.2 \mathrm{E}-07$ & & 7.4E-08 \\
\hline High and mid-tech manufacturing & 0.164 & ** & 0.070 & 0.850 & $* * *$ & 0.253 \\
\hline High-tech services & 0.166 & & 0.102 & 0.502 & & 0.408 \\
\hline \multirow[t]{2}{*}{ Selection term } & & & & 0.677 & $* *$ & 0.179 \\
\hline & $d y / d x$ & & Std. E. & $d y / d x$ & & Std. E. \\
\hline Exporter (t-1) & 0.054 & $* * *$ & 0.013 & & & \\
\hline Export intensity $(\mathrm{t}-1)$ & & & & 0.060 & ** & 0.026 \\
\hline Lack of finance & 0.000 & & 0.007 & -0.256 & ** & 0.117 \\
\hline Lack of information & -0.022 & $* * *$ & 0.008 & -0.095 & & 0.137 \\
\hline Proxies for market proximity & & & & & & \\
\hline Internal sources of information & 0.005 & & 0.012 & -0.294 & & 0.198 \\
\hline Institutional sources of information & -0.027 & $* *$ & 0.011 & 0.314 & & 0.241 \\
\hline Market sources of information & 0.041 & $* * *$ & 0.011 & 0.309 & & 0.218 \\
\hline \multicolumn{7}{|l|}{ Absorptive capacity } \\
\hline Continuous R\&D engagement & 0.024 & * & 0.014 & & & \\
\hline R\&D employment & 0.061 & $* * *$ & 0.019 & 0.459 & & 0.837 \\
\hline Multinational: subsidiary & 0.040 & $* *$ & 0.017 & 0.444 & * & 0.235 \\
\hline Patent & 0.044 & $* * *$ & 0.014 & 0.327 & & 0.242 \\
\hline Log likelihood: & & & & & 734.1 & \\
\hline Number of observations & & 2,759 & & & 359 & \\
\hline
\end{tabular}

Note: Std. E.: Estimated standard error. All regressions include the constant and dummies for geographical regions. Apart from coefficients, marginal effects $(d y / d x)$ are reported at sample means for the probability of locating $R \& D$ abroad and for the expected value of $R \& D$ expenditures at foreign locations (in log.) conditional on locating R\&D abroad. * Significant at 10\%. ** significant at 5\%.*** significant at $1 \%$. 
Table 3

Determinants of international R\&D outsourcing. Generalized Tobit model

\begin{tabular}{|c|c|c|c|c|c|c|c|c|c|c|c|c|}
\hline & \multicolumn{3}{|c|}{$\begin{array}{c}(1) \\
\text { Locating R\&D abroad }\end{array}$} & \multicolumn{3}{|c|}{$\begin{array}{c}(2) \\
\text { Foreign R\&D expenditure }\end{array}$} & \multicolumn{3}{|c|}{$\begin{array}{c}\text { (3) } \\
\text { Locating R\&D abroad }\end{array}$} & \multicolumn{3}{|c|}{$\begin{array}{c}(4) \\
\text { Foreign R\&D expenditure }\end{array}$} \\
\hline & \multicolumn{2}{|c|}{ Coefficient } & \multirow{2}{*}{$\begin{array}{l}\text { Std. E. } \\
0.076\end{array}$} & \multicolumn{2}{|c|}{ Coefficient } & \multirow[t]{2}{*}{ Std. E. } & \multicolumn{2}{|c|}{ Coefficient } & \multirow{2}{*}{$\begin{array}{l}\text { Std. E. } \\
0.075\end{array}$} & \multicolumn{2}{|c|}{ Coefficient } & \multirow[t]{2}{*}{ Std. E } \\
\hline Exporter (t-1) & 0.257 & $* * *$ & & & & & 0.295 & $* * *$ & & & & \\
\hline Export intensity $(\mathrm{t}-1)$ & & & & 0.049 & * & 0.029 & & & & 0.075 & ** & 0.029 \\
\hline Lack of finance: exporters & 0.039 & & 0.045 & -0.151 & & 0.138 & 0.031 & & 0.045 & -0.156 & & 0.149 \\
\hline Lack of finance: non-exporters & -0.089 & & 0.059 & -0.537 & ** & 0.248 & -0.096 & * & 0.058 & -0.610 & ** & 0.256 \\
\hline Lack of information: exporters & -0.159 & $* * *$ & 0.053 & -0.345 & $* *$ & 0.172 & -0.165 & $* * *$ & 0.052 & -0.459 & $* *$ & 0.183 \\
\hline Lack of information: non-exporters & -0.060 & & 0.072 & -0.037 & & 0.336 & -0.057 & & 0.071 & -0.048 & & 0.340 \\
\hline \multicolumn{13}{|l|}{ Proxies for market proximity } \\
\hline Internal sources of information & 0.034 & & 0.068 & -0.224 & & 0.213 & 0.042 & & 0.067 & -0.148 & & 0.232 \\
\hline Institutional sources of information & -0.164 & $* *$ & 0.072 & 0.074 & & 0.278 & -0.158 & ** & 0.072 & 0.107 & & 0.275 \\
\hline Market sources of information & 0.232 & $* * *$ & 0.067 & 0.596 & ** & 0.248 & 0.240 & $* * *$ & 0.067 & 0.775 & $* * *$ & 0.264 \\
\hline \multicolumn{13}{|l|}{ Absorptive capacity } \\
\hline Continuous R\&D engagement & 0.149 & & 0.091 & & & & 0.138 & & 0.088 & & & \\
\hline R\&D employment & 0.375 & $* * *$ & 0.113 & 1.007 & & 0.864 & 0.293 & $* * *$ & 0.110 & 0.451 & & 0.788 \\
\hline Multinational: subsidiary & 0.213 & $* * *$ & 0.080 & 0.748 & ** & 0.295 & 0.227 & $* * *$ & 0.080 & 0.883 & $* * *$ & 0.306 \\
\hline Patent & 0.238 & $* * *$ & 0.071 & 0.654 & ** & 0.288 & 0.262 & $* * *$ & 0.070 & 0.816 & $* * *$ & 0.298 \\
\hline Size & 2.9E-04 & $* * *$ & $8.5 \mathrm{E}-05$ & 0.001 & $* * *$ & 0.0004 & & & & & & \\
\hline Size squared & $-3.0 \mathrm{E}-08$ & $* * *$ & $1.2 \mathrm{E}-08$ & $-1.2 \mathrm{E}-07$ & $*$ & 7.4E-08 & & & & & & \\
\hline High and mid-tech manufacturing & 0.159 & $* *$ & 0.070 & 0.846 & $* * *$ & 0.248 & 0.153 & ** & 0.070 & 0.835 & $* * *$ & 0.260 \\
\hline High-tech services & 0.177 & $*$ & 0.104 & 0.517 & & 0.411 & 0.176 & $*$ & 0.102 & 0.661 & & 0.415 \\
\hline \multirow[t]{2}{*}{ Selection term } & & & & 0.677 & ** & 0.176 & & & & 0.767 & $* * *$ & 0.116 \\
\hline & $d y / d x$ & & Std. E. & $d y / d x$ & & Std. E. & $d y / d x$ & & Std. E. & $d y / d x$ & & Std. E. \\
\hline Exporter (t-1) & 0.045 & $* * *$ & 0.014 & & & & 0.058 & $* * *$ & 0.015 & & & \\
\hline Export intensity (t-1) & & & & 0.049 & * & 0.029 & & & & 0.075 & ** & 0.029 \\
\hline Lack of finance: exporters & 0.007 & & 0.008 & -0.204 & & 0.127 & 0.006 & & 0.009 & -0.209 & & 0.133 \\
\hline Lack of finance: non-exporters & -0.015 & & 0.010 & -0.418 & $*$ & 0.245 & -0.019 & $*$ & 0.011 & -0.448 & * & 0.245 \\
\hline Lack of information: exporters & -0.027 & $* * *$ & 0.009 & -0.132 & & 0.138 & -0.032 & $* * *$ & 0.010 & -0.180 & & 0.143 \\
\hline Lack of information: non-exporters & -0.010 & & 0.012 & 0.043 & & 0.320 & -0.011 & & 0.014 & 0.048 & & 0.321 \\
\hline \multicolumn{13}{|l|}{ Proxies for market proximity } \\
\hline Internal sources of information & 0.006 & & 0.011 & -0.269 & & 0.194 & 0.008 & & 0.013 & -0.219 & & 0.203 \\
\hline Institutional sources of information & -0.027 & $* *$ & 0.011 & 0.295 & & 0.235 & -0.029 & $* *$ & 0.013 & 0.375 & & 0.231 \\
\hline Market sources of information & 0.039 & $* * *$ & 0.011 & 0.284 & & 0.212 & 0.045 & $* * *$ & 0.012 & 0.369 & * & 0.218 \\
\hline \multicolumn{13}{|l|}{ Absorptive capacity } \\
\hline Continuous R\&D engagement & 0.024 & * & 0.014 & & & & 0.025 & * & 0.015 & & & \\
\hline $\mathrm{R} \& \mathrm{D}$ employment & 0.065 & $* * *$ & 0.019 & 0.504 & & 0.813 & 0.057 & $* * *$ & 0.021 & -0.044 & & 0.763 \\
\hline Multinational: subsidiary & 0.040 & $* *$ & 0.017 & 0.464 & * & 0.246 & 0.048 & $* * *$ & 0.018 & 0.504 & ** & 0.248 \\
\hline Patent & 0.044 & $* * *$ & 0.014 & 0.338 & & 0.239 & 0.055 & $* * *$ & 0.016 & 0.378 & & 0.243 \\
\hline Log likelihood & & & & & 731. & & & & & & $-1,74$ & \\
\hline Number of observations & & 2,759 & & & 359 & & & 2,75 & & & 35 & \\
\hline
\end{tabular}

See notes from Table 2 . 